\title{
LIMITATIONS OF ANTI-TRUST LEGISLATION
}

\author{
By James M. Beck, \\ New York.
}

I am here to-night in the capacity of a Greek chorus. I am not so antique and $I$ am sure not half so intelligent. The Greek chorus fulfilled its mission of commenting upon that which the chief actors had said, and whether it was the hero or the villain, it commented with breadth of view and judicial impartiality. Therefore being but a chorus and not an actor, I must be brief. There is another reason that requires brevity and also discretion in my few comments. As the chairman has said I professionally represent as its general counsel one of the big interests against which the attorney-general has directed his zealous and skilful activities. I am therefore in the position of defendant in a United States court at Philadelphia when I was district attorney. A strong case had been proved against him on a charge of selling liquor without a federal license, and his attorney, knowing that Judge Butler most despised a perjurer, counseled him not to testify but to keep off the stand. The colored man said, "All right. I 'spects I had better remain neutral." There is a third reason why I want to be brief in my remarks, and that is, as I still account myself of Philadelphia, and as a speaker, a distinguished member of congress, from another state, is to follow me, I would only postpone your pleasure and do him an injustice if I unduly prolonged my remarks, and I would be wanting in courtesy if I encroached upon the time which remains to him before the arrival of the President.

I was much impressed with the fact that each of the preceding speakers treated a different phase of the warfare of the government against modern methods of doing business, and that each gave some testimony as to the practical results of his especial line of work. The attorney-general, on the one hand, spoke of the great legal department of the government, spoke, not only for himself in the successful work which he has done as attorney-general, but in a sense for all his predecessors in that high office since the enactment of the Sherman law. And the only tangible result of the enforce- 
ment of the Sherman law to which he called attention, was of some competition in Kentucky, in the sale of leaf tobacco, and the fact that the stockholders of Standard Oil had some thirty-six instead of one certificate of shares for their property holdings in that most efficient business organization. Now that there has been or will be any radical change in the underlying conditions of any industry, by reason of any activity of the government under the Sherman law, I do not believe. This attempted enforcement of the law represents a part of possibly an irrepressible conflict between the man and the state, and just as in past ages by many centuries of sacrifice it was demonstrated that the most powerful government cannot crush the religious opinions of men, so I believe that, whether it takes years or decades, sooner or later the people will realize that the vast economic forces of our country representing the interplay of a hundred complex tendencies, all stimulated and invigorated by the agencies of steam and electricity, cannot be held in by any legislative straight-jacket or bureaucratic supervision. The second speaker, Senator Newlands, spoke for the legislative branch of the government, and he told us how for many months distinguished men appeared before the Committee on Interstate Commerce, and gave the best of their efforts to amendatory legislation of the Sherman law, and he admits that all has ended in empty discussion. You will remember how when the Queen in Carroll's classic took Alice by the hand and ran with her until Alice was breathless, how Alice found she was where she was when she started, and said, "In my country when we run very fast we get somewhere." The Queen said, "Oh, well, that is true in your country, but in this country you have to run twice as fast as that to even stay where you are." All this talk about adding to the already restrictive regulations of the Sherman law will be quite as futile as Alice's journey, unless it confines itself to very specific instances of commercial wrongdoing, which are susceptible of a clear, intelligent and tangible prohibition.

And finally we come to the third speaker, the able Commissioner of Corporations, and what deeply impressed me was the fact that he showed practical results, and how had they been accomplished? Simply by the efficient dissemination of intelligence and the appeal to a force greater than courts, greater than the attorneygeneral, greater than congress, the dominating force in any democratic commonwealth, the force of public opinion. And so far as 
the Sherman law admits of an application through executive channels I believe it will come in just such an appeal to public opinion.

From the year 1787, when our constitution was adopted, until 1887, a full century later, there never was a statute of congress attempting in any affirmative or even negative way to police these so-called channels of interstate trade. There were congressional enactments to aid in the construction of railroads, for the construction of railroads was then regarded as of a highly useful character, so much so that when the last spike was driven in the Union Pacific Railroad it was made an occasion of great rejoicing in many eastern cities. There was then no hostility against the railroads. Until 1887 there never was an attempt for a full century to enact any law to restrict or curb the commercial activities of the American people, and yet we got along very well. We grew and grew greatfrom three millions in 1787 to sixty odd millions in 1887 . We grew to be one of the greatest nations in the world in agriculture, mining and manufacturing, and I venture to say that, in 1887, there was more general good feeling among all classes of the American people, a greater advance of prosperity, there was greater freedom for capital to make its investments and greater prosperity for labor than there has been since the government attempted, by legislative methods, to interfere with the delicate mechanism of business. Two countries illustrate two opposite poles, of thought in this respect, the mother country, England, and our own country. With the exception of recent attempts to liberate and elevate those of the manual toiling class, England has adopted and still adopts the policy of laissez faire. Let me give you a striking illustration. Although our country has a mass of conflicting insurance legislation, do you know in what the only insurance legislation of England consists? It is simply that every insurance company shall file a report with the Board of Trade, giving the financial status of its business, and if any official makes a single false statement, the prosecuting officer sends him to jail. There is, however, no attempt to fetter the freedom of trade between the insurance companies and the public. In other words, instead of treating adults as minors, they let the individual read his contract, protect himself, and not act as an infant for whom the government should be a kind of guardian. In our country we have a conflicting mass of insurance legislation which puts the insurance company upon the level of a Chinese merchant, 
who, passing through the sixty cantons of China, is obliged to pay tribute to the corrupt mandarin of each province. Nevertheless we had the great insurance scandals in this country, and some one suggested in England that they ought to abandon the policy of noninterference, and at least regulate all foreign insurance companies in England. I had the honor of appearing on behalf of the Mutual Life Insurance Company before a special committee of the House of Lords, and they concluded that the old policy of England of preventing only fraud, but otherwise allowing the companies and the individual entire freedom of contract, was the one upon which England has grown great.

I cannot, in the few moments that I have, even state my meaning, much less amplify it. I do not advocate any hard and fast doctrine of laissez faire. Some of our experiments in regulating business have yielded good results. The Interstate Commerce Act of 1887 , to which the senator has alluded, has more than justified itself, and has given to each shipper an equal chance, and has slapped a practice under which a railroad could allot to one man prosperity and to another poverty. It is a magnificent demonstration of intelligent public action. The Sherman anti-trust law is not thus vindicated by results. Far from accomplishing its object, all the great industrial organizations, with the single exception of the Standard Oil, the distillery trust and the American Sugar Co., have grown up since the enactment of the law. I do not say the law stimulated them, I simply say the law was impotent to stop them, because it was an irresistible economic impulse to combine a number of units into a more efficient unit. Who has been injured? There has been, since the Sherman law was passed, a standing invitation in that law to any individual who felt himself aggrieved by reason of any combination, to commence a suit, and obtain, not only the uttermost penny of what he has suffered, but three dollars for every dollar of injury. I refer to the treble damage clause of the Sherman anti-trust law, and I do not believe-I think I am safe in saying it-that in the twenty-two years since the enactment of the law there have hardly been twenty-two instances in which any individual ever sued a combination under the treble damage clause. There has never been, unless it has happened while we are speaking to-night, but one instance of a jury convicting a company under the penal provisions of the Sherman anti-trust law. There is one 
exception (the turpentine case), and the Supreme Court of the United States has entertained an appeal as matter of grace to determine whether the penal provisions are not so unintelligible as to be void under the organic law of the nation. You have these two facts, that only once, so far as experience shows, has a jury made criminals of men because they do what manifestly has been a great economic impulse of the closing years of the nineteenth century and the beginning of the twentieth century, and that no individual, whether he had large means or little, with the comparatively few exceptions to which I have referred, has ever taken advantage of the treble damage clause to show that he has suffered by reason of the combinations. If there was this genuine popular indignation against the trusts, so-called, I am inclined to think the courts would be full of cases of this character. A mere inspection of a manual of statistics will convince any intelligent man that there are at least one thousand corporations having some large relative percentage of control of a particular industry, against which no action has or could be brought, because if the present interpretation of the law were applied indiscriminately to every corporation within its scope, the courts would be so clogged by litigation that there would be little time in the federal courts for anything else. The Sherman law in its practical enforcement has been, notwithstanding the high purposes, the great skill, and the real effort of the various attorneys-general who have had occasion to administer it, little less than a delusion. It has accomplished practically nothing. It has not altered the underlying basis of any industry, and it never will, because you cannot compel men to compete if they do not want to compete.

If the Sherman law is to remain, then I would relieve the political department of the government from the duty of its enforcement. I know the attorney-general and I know something of the department there, and believe me, there is no more efficient machine than the federal machine, and no higher class of officials in the world than those, who, like Mr. Wickersham, put aside great material advantages to serve the country in official station. We do not half appreciate the men in Washington who on meagre salaries serve us so efficiently, and this could be said of all three of the speakers here to-night. Nevertheless, this fact is as true as human-nature, that so long as the success or failure of an administration must depend for the time being upon its temporary popularity, there 
will always be a sub-conscious influence, to some extent, impelling any man in power to do that which is popular and so long will there be an obvious temptation to institute these suits on the civil side of the court. They become a political asset of inestimable value, and they have proved in the past no inconsiderable factor in the re-election of an administration. To remove that pernicious mingling of politics and business I would take out of the Sherman law, just as is done in the Interstate Commerce law, any initiative on the part of the government. I would leave it to the individual who claims to have been injured, to demonstrate the truth of his allegations in a court of justice.

I would repeal the penal provisions of the Sherman law, which have been practically a dead letter, and which have accomplished nothing of value, and which could be used, as they have never yet been used, but could be used, as a real engine of oppression. I would constitute a tribunal in Washington and I would not make it wholly or largely of lawyers. This whole question has been plunged into a fathomless morass by legal terms and legal technicalities until no business man knows what a reasonable restraint of trade is. The courts do not-understand it. I defy anybody to read the sixteen thousand words of the Tobacco Trust and Standard Oil decisions and form even a vague idea of what is a reasonable restraint or what is unreasonable. If the Supreme Court of the United States, after two years of deliberation and the use of sixteen thousand words cannot give a plain definition of what a business man may do or may not do, then these business men ought not to be charged with violations of law if they mistake their way in this jungle of legal terms. I would constitute this tribunal non-partisan, naming five business men and four lawyers. I would then do precisely as they do in Canada. Any person claiming that his liberty to compete is restrained should go before that tribunal and be given a summary hearing to see if there was any substantial basis for the complaint. If there is found to be, let the finding be certified to the courts and unless the corporation can show cause to the contrary, let the court issue a writ of injunction or a temporary mandamus to right the wrong that strangles competition. With respect to the real element which affects the public, namely the question of extortionate prices, I would apply, if we are going to abandon the principle of laissez faire, and attempt to solve this most difficult 
problem by legislation, to the corporation the principle contained in what we know as Munn vs. the State of Illinois. In that case it is held that whenever a corporation is of such a character as to be a semi-public agency, as a public utility corporation, an electric light company, a railway, an elevator company, or a ferry, then to prevent extortion the state had the right by maximum charges to stop the quasi-governmental body from making more than a reasonable return upon its actual investment of capital. Therefore I would have this governmental tribunal upon complaint of a given number of consumers, make an investigation and if it found that the party charged did by reason of its magnitude of capital as compared with the capital of competitors or by its relative percentage in the trade or by any other circumstance, have as a fact such a control of sources of supply, or for any reason such a monopolistic control over the industry, then I would treat it as I would treat a railroad, an electric light company, or any other public utility as charged with a public use; I would find out what was its actual investment and by a maximum price give it a fair return on its investment and no more. But if it were not a monopolistic combination, then I would leave, with respect to the price of the product, free play to economic forces.

I have taken a great deal more time than I had any idea of, and I must apologize to you and to the next speaker, and I only want to say that if, in the hurry of these desultory remarks I have even seemingly said anything offensive to any other speaker, then let me say, in the words of Hamlet:

Let this disclaiming of a purpose evil

Free me so far in your most generous thoughts, That I have shot an arrow o'er the house And hurt my brother. 